\title{
E A CHAMINÉ? RELATOS ETNOGRÁFICOS SOBRE POLÍTICAS PÚBLICAS E A TERRA INDÍGENA (TI) DE PANAMBIZINHO
}

\author{
ROGÉRIO ANDRADE ${ }^{1}$
}

$U F G D$

SIMONE BECKER ${ }^{2}$

$U F G D$

\begin{abstract}
RESUMO: O processo de colonização da região do Mato Grosso vincula-se àquele da criação de reservas (de confinamento) no lócus atualmente conhecido como sul de Mato Grosso do Sul. As guerras cotidianamente travadas entre latifundiários e indígenas em razão das demarcações de territórios reivindicadas por Kaiowá, Guarani e Terena, a nosso ver, não podem se dissociar da contextualização macrossociológica e diacrônica da formação do sul do jovem estado de Mato Grosso do Sul. Em meio a este cenário, a Terra Indígena de Panambizinho, por ser regulamentada, parece não fugir aos problemas voltados à ação nociva do Estado, face aos meios de vivência destinados aos Kaiowá que são inumanos. Como continuidade de pesquisas iniciadas desde 2008, o presente artigo, a partir da realização de imersões a campo, contribui para as discussões mais amplas sobre sociedades indígenas e políticas públicas, tendo como fio condutor a experiência dos Kaiowá de Panambizinho junto à iniciativa do governo federal intitulada de "carteira indígena"; à recepção elou chegada do fogão ecológico via PNUD e às propostas retiradas do II Seminário de Saúde Mental Indígena, ocorrido em Dourados.
\end{abstract}

PALAVRAS-CHAVE: Políticas Públicas; TI Panambizinho; Kaiowá.

ABSTRACT: The process of colonization of the region of Mato Grosso is linked to the process of establishment of reservationa (confinement) in the locus now known as south of Mato Grosso do Sul. The war daily fought between landowners and indigenous on account of the demarcation of territories claimed by Kaiowá, Guarani and Terena, in our view, cannot be dissociated from the macro-sociological and diachronic context of development of the southern region of the young state of Mato Grosso do Sul. In this scenario, the Indigenous Land of Panambizinho, yet to be regulated, apparently isn't excused from problems that come from State deeds, given that the means of living destined to the Kaiowá are inhuman. As continuation to the research initiated in 2008, this article contributes through field work to broader discussions about indigenous societies and public policies, having as thread the experience the Kaiowá from Panambizinho had with the governmental iniciative entitled "Carteira Indigena", the arrival of ecological stoves by UNDP and the propositions from the Second Indigenous'

\footnotetext{
${ }^{1}$ Pós-Graduando em Direitos Humanos e Cidadania pelo Programa de Pós-Graduação Lato Senso em Direito - FADIR/UFGD; Mestrando em Sociologia pelo Programa de Pós-Graduação em Sociologia FCH/UFGD; Graduado em Direito pela Faculdade de Direito de Bauru - Instituição Toledo de Ensino, Bauru/SP. E-mail: rogerioandradeufgd@gmail.com .

2 Diretora da Faculdade de Direito e Relações Internacionais - FADIR/UFGD; Docente Permanente do PPGANT/UFGD; Doutora em Antropologia Social pela UFSC; Mestre em Antropologia Social pela UFPR; e Graduada em Direito pela PUC/PR. E-mail: simonebecker@ufgd.edu.br .
}

Espaço Ameríndio, Porto Alegre, v. 7, n. 2, p. 172-204, jul./dez. 2013. 


\section{Introdução}

O presente artigo é resultado de confluências de trabalhos de campo e ações de pesquisa e de extensão já findos ou em desenvolvimento, cujo foco reside na exposição de alguns dos percalços que os Kaiowá da Terra Indígena ( $\mathrm{Tl}$ ) Panambizinho enfrentam no que toca à própria sobrevivência. Abordaremos como se efetivam (ou não) as políticas públicas, partindo do resgate social e histórico da não inserção dos indígenas da região na sociedade hegemônica "nacional" não indígena.

Quanto aos aspectos metodológicos, destacamos que fora feito trabalho de campo por uma das autoras desde 2008, na qual foi observada, em 2010, a tentativa frustrada da implantação de políticas públicas com o propósito de promover a segurança alimentar da comunidade, chamada de "Projeto Carteira Indígena". A partir de agosto de 2013, ambos os pesquisadores retomaram os estudos na referida TI, entretanto, nesta nova inserção, debruçamo-nos sobre a intervenção efetuada por meio do Programa das Nações Unidas para o Desenvolvimento (PNUD), com a implementação do "fogão ecológico". Para além das idas à TI de Panambizinho, também acompanhamos com o fito de pesquisa o I/ Seminário de Saúde Mental Indígena, realizado na cidade de Dourados/MS, entre os dias 07 e 10 de agosto de 2013.

Com a análise das propostas levantadas no Seminário pelas lideranças indígenas e representações estatais correlacionadas com as demandas frustradas e equivocadas observadas na comunidade resultou o título do nosso trabalho. Por conseguinte, a falta da "Chaminé" do fogão ecológico, escutada por nós de um de nossos interlocutores de Panambizinho, ultrapassa o sentido concreto e se transforma numa polissemia ou pluralidade de sentidos, uma vez que a condição destes povos no processo colonizador foi marcada pelo "sufocamento" ou a 
falta de respiro para o bem-viver dos povos indígenas. Portanto, o presente trabalho propõe apresentar ao leitor um pequeno recorte desta realidade da TI Panambizinho; e colocar em discussão o que tem sido feito (ou não) de políticas públicas junto a esses povos.

1. Processo de colonização do atual Estado do Mato Grosso do Sul - MS, então Mato Grosso - MT

\subsection{Dos aspectos macrossociológicos envolvendo processos de colonização na América Latina e em solos brasileiros}

Antonio José Guimarães Brito (2012), citando Zimmermann (1997), salientou que o paradoxo que cerca a história da América Latina está na grande desigualdade social, tendo como cenário um quantitativo extenso de terras que gera imensas riquezas para poucos. $O$ desencadeamento desta lógica dentro da sociedade brasileira continua a produzir seus efeitos, em especial no que toca às comunidades tradicionais indígenas (PACHECO, 2013) e àquelas ao sul de Mato Grosso do Sul. Sabedores de que as ingerências históricas sobre o processo de territorialização deram-se atreladas à colonização (arbitrária) por parte do Estado (BRAND, 1997; LENHARO, 1986), há que se destacar, como bem o faz a antropóloga Katya Vietta (2007), que não se trata de uma via de mão única. A teórica debruça-se sobre os Kaiowá de Panambizinho, mas podemos estendê-los as demais comunidades. Se não, vejamos:

Por um lado, têm-se as condutas territoriais do Estado expressas através dos projetos que promove ou apoia, por outro estão as percepções kaiowá sobre as suas terras, o que também diz respeito às suas formas de interagir (ou de reagir) a estes projetos (VIETTA, 2007, p. 271).

Nesta esteira, a colonização do então Mato Grosso, atualmente, chamado de Mato Grosso do Sul constitui(u)-se num processo de tensão contínua entre índios e não índios, e entre os próprios indígenas. Esta tensão se apresenta nos conflitos agrários, fundiários em que se erguem 
fronteiras.

Segundo José de Souza Martins:

O que há de sociologicamente mais relevante para caracterizar e definir a fronteira no Brasil é, justamente, a situação de conflito social. E esse é certamente, $\mathrm{o}$ aspecto mais negligenciado entre os pesquisadores que têm tentado conceituá-la. Na minha interpretação, nesse conflito, a fronteira é essencialmente o lugar da alteridade (MARTINS, 2009, p. 133).

Neste sentido, o conflito histórico que sofre esse espaço fluído da fronteira "reserva/urbano" de Mato Grosso do Sul, é "lugar de descoberta do outro e de desencontro" (MARTINS, 2009, p. 133). Por conseguinte, os interesses da colonização de exploração, da metrópole portuguesa e, após 1822, pelo Estado brasileiro (imperial e republicano) foram de criar uma espécie de "alteridade mortal" em que para a existência do colonizador é necessária a eliminação ou a "fusão" do colonizado, o que Martins destacará que "[...] nós já não somos nós mesmos porque somos antropofagicamente nós e o outro que devoramos e nos devorou" (MARTINS, 2009, p. 134). Assim, o encontro ou rompimento das fronteiras sempre será marcado pela mudança do "eu" sobrevivente que assume outras formas para construir ou desconstruir a história. Por conseguinte, Martins (2009) ressalta que no Brasil a fronteira aparece com maior frequência no limite do humano. Logo, fora deste limite viceja o não humano, desumanizados e/ou inumanos.

Com relação a esta tática do Estado-Nação na desumanização de seres humanos, Butler destaca que:

A questão não é apenas que alguns humanos sejam tratados como humanos e outros sejam desumanizados; antes, é que essa desumanização tratar alguns humanos como seres à margem do escopo da lei - se torna uma das táticas pelas quais uma civilização "ocidental" supostamente distinta busca se definir em relação e por oposição a uma população compreendida, por definição, como ilegítima (BUTLER, 2007, p. 231).

Portanto, além da produção da condição da não humanidade - 
apesar das resistências que emergem dos indígenas nas relações com o Estado - destacada por Martins (2009) e da imposição de ilegitimidade a esses povos, sublinhamos como a lógica do colonialismo de exploração desconsidera(va) os povos indígenas. Inicialmente, como humanos que já ocupavam o território do Brasil colônia (BECKER, SOUZA e OLIVEIRA, 2013). Deste modo, podemos de partida estabelecer que o conflito de interesses e as fronteiras humanas se erguem: de um lado o modo de vida dos povos indígenas e sua relação preponderantemente cosmológica (OLIVEIRA e FARIA, 2009); e de outro lado, o modo de vida do colonizador orientado pela metrópole portuguesa em ocupar o território do Brasil colônia a todo o custo, até mesmo procriando com os nativos ${ }^{3}$, como destaca Edward Telles (2003).

Destarte, parece-nos que não há como nos dissociar da prevalência da lógica do capitalismo pautada na propriedade (privada) para analisarmos o cenário atual. Nadia H. Silveira (2011) enfatiza como em pleno Século XXI, no MS, vige uma discrepância pautada na terra de e para poucos, incluindo a questão dos alimentos que de seus solos férteis são produzidos. Se não, vejamos:

Num levantamento sobre a situação de segurança alimentar dos povos indígenas no Brasil1, realizado em 1995, constatou-se que no centro-oeste, $35 \%$ da população avaliada estava na faixa da fome, isto e, sem sustentabilidade alimentar. Em Mato Grosso do Sul, os grupos identificados como os mais vulneráveis foram os Kaiowá e Guarani [...]. Em 2005 essa situação atingiu o ápice, quando cerca de 20 criancas kaiowá e guarani, provenientes de varias aldeias em Mato Grosso do Sul, morreram por desnutrição grave (SILVEIRA, 2011, p. 26).

A função social da terra no Brasil é historicamente desviada para atender aos interesses de uma minoria que controla o Estado. Um exemplo são os estudos dos geógrafos Ariovaldo Umbelino de Oliveira e Camila Faria (2009). Os autores destacaram que a somatória das áreas da propriedade privada da terra no Brasil não corresponde ao total do território nacional. Dos 850 milhões de hectares, 102 milhões são de

\footnotetext{
${ }^{3}$ Desde 1755 o Rei de Portugal já encorajava seus súditos no Brasil a "povoar" a região e "juntar-se aos nativos através de matrimônio". Ato condenável e não reconhecido pela Igreja Católica da época (TELLES, 2003).
}

Espaço Ameríndio, Porto Alegre, v. 7, n. 2, p. 172-204, jul./dez. 2013. 
área de conservação ambiental; 128 milhões para as terras indígenas; aproximadamente 420 milhões são imóveis cadastrados pelo Instituto Nacional da Colonização e Reforma Agrária (INCRA); 30 milhões da área total ocupada por águas, áreas urbanas, rodovias e outras posses que deveriam ser regularizadas. Outros 170 milhões de hectares são de terras devolutas, em grande parte, apropriadas ilegalmente por grandes proprietários.

Por conseguinte, a lógica "capitalista rentista" (OLIVEIRA e FARIA, 2009) da terra, assim como o caráter integracionista do Estado Brasileiro em relação aos povos indígenas persiste e tem seu reflexo hodierno, por exemplo, em decisões do Tribunal de Justiça de Mato Grosso do Sul (TJMS). Becker, Souza e Oliveira (2013) sugerem como as desconsiderações de feituras de perícias antropológicas em processos criminais envolvendo indígenas indicam a prevalência da lógica do período histórico anterior à $\mathrm{CRFB} / 88$, mais especificamente do Estatuto do Índio (BRASIL, 1973) e seus preceitos assimilacionistas.

Outro fato importante desta lógica cristalizada na sociedade brasileira e nos poderes do Estado Nacional que buscam desagregar, dividir e dissipar as forças das sociedades indígenas que resistiram e resistem aos séculos à violência reside na criação das reservas voltadas ao confinamento de indígenas. No entendimento de Levi Marques Pereira (2011) esta situação de reserva provoca a desorganização das sociedades indígenas, a reboque do que já produzira Antonio J. Brand (1997). Cabe aprofundarmos esta questão atrelada ao caso de Panambizinho, cujas terras foram homologadas e repassadas aos Kaiowá em 2005.

1.2. O processo de colonização via confinamento na microssociologia das comunidades kaiowá em Dourados/MS e TI de Panambizinho

\footnotetext{
"Por que o branco ia chegando e o Kaiowá ia se escondendo onde ainda tinha mato. Mas quando chegou a Colônia, não tinha mais onde se esconder!" Índio Kaiowá Nailton Aquino, da Terra Indígena (TI) Panambizinho (VIETTA, 2007, p. 204, sic).
}

Espaço Ameríndio, Porto Alegre, v. 7, n. 2, p. 172-204, jul./dez. 2013. 
O trecho em destaque aponta como a política de expansão demográfica, projeto do Estado Novo, foi devastadora para os povos Kaiowá ${ }^{4}$ de MS. Todavia, sinaliza, também, para o Estado brasileiro investido do ideal nacionalista, dos anos de 1930 e de 1940, quando criou as Colônias Agrícolas Nacionais (CAN), como podemos verificar em estudos de Nely Aparecida Maciel (2012) citando Couto de Oliveira (1999):

[...] a política de colonização do governo Vargas, no período do Estado Novo, teve como fio condutor a ocupação dos espaços vazios, o que ocorreu por meio da mobilização de trabalhadores rurais, incentivados pela possibilidade de se tornarem proprietários. No início da década de 1940, o governo federal, criou as Colônias Agrícolas Nacionais (CAN), destinadas ao assentamento de colonos (OLIVEIRA apud MACIEL, 2012, p. 34).

A autora destaca, porém, que os títulos de propriedades, que os colonos receberam do antigo Mato Grosso, proveniente da Colônia Agrícola Nacional de Dourados (CAND), não eram legítimos, uma vez que contrariavam a Constituição de 1891 que desconsideravam como devolutas as terras ocupadas por índios, portanto impassíveis de serem negociadas. Assim, outro motivo que Maciel (2012) destaca é que o Estado brasileiro não poderia praticar alienação dessas, pois são terras indígenas, conforme adiante esmiuçaremos.

Maciel (2012) salientou, igualmente, que as terras pertencentes aos índios foram rapidamente desmatadas. A mão de obra indígena foi utilizado enquanto havia mata para derrubar, após, eram pressionados a mudarem para as Reservas Indígenas (RI) ou Postos Indígenas (PI). Isso prevaleceu até a década de 1970 (BRAND apud MACIEL, 2012).

Deste modo, os indígenas foram desapropriados de suas terras, e para sobreviver buscaram a Reserva Indígena (RI) ou o Posto Indígena (PI) para se instalar, ocasionando alta densidade populacional e graves conflitos. No relato da Kaiowá Ramona Mônica, a mesma acrescenta que:

Fizeram a estrada [BR 163], depois veio o trator! Antes tinha só mato, de [rio] Dourados, pra cá, até o rio

\footnotetext{
${ }^{4}$ Não apenas para eles, mas como se trata de um de nossos focos será este o acento que produziremos.
} 
Brilhante, era só mato! Depois a Colônia mexeu e acabou! Os Kaiowá que se juntarem todos aqui... (Região de Panambizinho) (VIETTA, 2007, p. 213).

No entendimento de Levi Marques Pereira, neste aglomerado de representatividades num mesmo território, os líderes serão como: "exilados em terra estranha, seus líderes não serão reconhecidos pelos líderes locais, e serão alvo predileto para as acusações de toda ordem" (PEREIRA, 1999, p. 213).

Em Panambizinho, o critério de distribuição de terras da CAND foi o mesmo tanto para os Kaiowá quanto para os "brancos", não observando os critérios específicos da cultura indígena como o tekoha ${ }^{5}$; e os preceitos constitucionais vigentes na época, como a desconsideração das terras devolutas como de ocupação dos indígenas. Quanto à questão da forma equivocada como a interpretação das terras devolutas, cabe remissão às explicações de Diego Cristofari Correia (2012, p.116-117):

Com base neste preceito constitucional, a maioria dos estados federados do Sul (incluído neste o então Mato Grosso) Sudeste e Nordeste, mediante uma interpretação parcial da Lei de Terras, passou a considerar as terras de ocupação primária ${ }^{6}$ e de aldeamentos não extintos, como devolutas, comercializando-as com os neocolonizadores (AZANHA, 2001, p. 07).

A interpretação em apreço fundava-se na definição dada pela Lei no 601/1850 (ou Lei de Terras) sobre as terras devolutas, a saber: são "aquelas que não estão sob o domínio dos particulares, sob qualquer título legítimo, nem aplicadas a algum uso público federal, estadual ou municipal" (IDEM, p.01). De forma equivocada, os governantes dos estados federados consideravam que as terras indígenas não eram destinadas a nenhuma das referidas finalidades arroladas na definição dada pela Lei no 601/1850.

No entanto, tal interpretação não se sustenta em face da análise da Lei Terras com sua Lei Regulamentadora (Regulamento $n^{\circ} 1318$ de 1854), visto que esta em seu

\footnotetext{
${ }^{5}$ Para os fins deste trabalho, a despeito de toda a complexidade do conceito desde Melià, passando por Mura e Pereira, enfatizamos o utilizado por de Maciel: "[...] é todo espaço em que vivem e seguem seus costumes, suas tradições, onde se organizam e acontecem os eventos sociais e políticos, como, festas, danças, rezas, casamentos, reuniões e outros. O tekoha é liderado por uma pessoa mais velha, como lideranças religiosas e políticas" (MACIEL, 2012 ,p. 58).

${ }^{6} \mathrm{Ou}$ havidas de primeiro ocupante.
}

Espaço Ameríndio, Porto Alegre, v. 7, n. 2, p. 172-204, jul./dez. 2013. 
artigo 72 determinava que fossem reservadas das terras devolutas nos distritos onde existiam "hordas selvagens", aquelas indispensáveis para colonização e aldeamento de indígenas (CORREIA, 2012, p. 116-117, sic).

Retornando às especificidades dos Kaiowá de Panambizinho, o que prevaleceu antes da homologação, foi a divisão por lotes, assim, dispondo o Estado de 30 hectares por família. No entanto, os indígenas que receberam os lotes foram pressionados a vendê-los ou trocá-los com os colonos. Duas famílias kaiowá resistiram às pressões, permanecendo em dois lotes: de Pa'i Chiquito e de seu filho, Martins Capilé (MACIEL, 2012).

Conforme relato do Kaiowá Ricardo Jorge, destacado por Silva:

Colônia chega em 1944[...] Chegaram os índios em Dourados (no PI) um a um explicaram que o branco ia chegar: se tinha morador índio, branco não entrava; quando não morava índio, era lote de branco. Já misturou civilizado com índio pra tomar tudo. Cortaram em lote e deram uma escritura para os índios velhos, enganado, tudo enganado. Era um papel pequeno. Ficou um ano misturado, depois o Administrador chamou os índios para avisar que não pode misturar. Ruivito, meu pai, morava no lote 44, recebeu ordem para ir para a aldeia de Dourados. Foi assim com todos. Pedro Henrique, Dominguinho, Livino, Paraguassu brigaram com os colonos e conseguiram ficar em Lagoa Rica. Raul vendeu terra dos índios para colono e a escritura que deu para o índio teve que devolver. Pedro Henrique morava no 43, na beira do Braço Morto, brigou com Antonio e Miguel Rosa (colono), botou fogo na casa de Henrique e do Lídio e ainda sai risando do índio. Os dois saíram na marra e defendeu o que pode pegar (SILVA apud MACIEL, 2012, p. 60).

Observamos pelo trecho do relato acima a tensão existente entre os índios e colonos, em grande medida até os dias atuais (retro)alimentado pelos discursos dominantes. Há que se frisar que os Kaiowá não distinguem (tradicionalmente) "território" conforme determinados "não índios", pois, guiados pelo tekoha as famílias extensas ou parentelas ampliadas continuaram vivendo conforme o costume, daí os "papéis se misturarem". Por conseguinte, aproveitando 
desta faceta, os administradores faziam pressão para os Kaiowá mudarem para o posto indígena de Dourados. Contudo, Pai Chiquito Pedro e a sua parentela ampliada (VIETTA, 2007), incluindo seu filho, Martins Capillé, continuaram nos dois lotes distribuídos pela CAND. Todavia, estes lotes, até a implantação do TI de Panambizinho (2005) continuariam a ser alvo de demandas judiciais de colonos reivindicando sua posse (MACIEL, 2012). Após longa batalha jurídica (e política) os Kaiowá conquistaram enfim o seu Tekoha, constituído de aproximados 1272 hectares, conforme podemos verificar no mapa abaixo (MACIEL, 2012, p. 77):

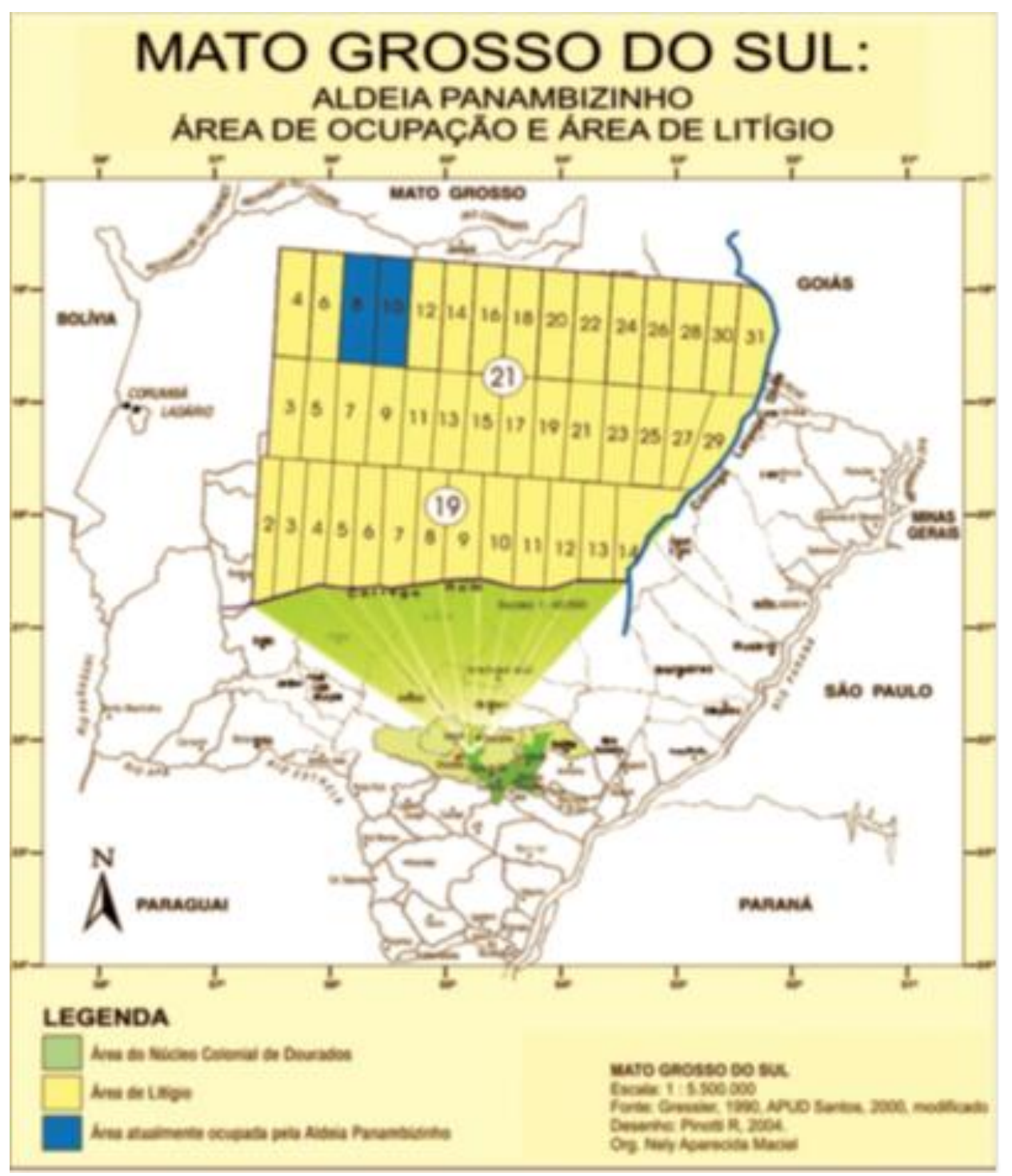

Figura 1. TI Panambizinho. Fonte: Santos (apud Maciel, 2012)-[modificado]. 
Os lotes em azul da Figura 1 são as terras antigas (os 60 hectares) de Pai Chiquito Pedro e Martins Capillé, atualmente nestes lotes funcionam a escola e o posto de saúde, de maneira similar relatada por um de nossos interlocutores, Reginaldo Aquino da Silva, agente de saúde indígena em Panambizinho.

2. O trabalho de campo: o projeto Carteira Indígena 2010 da $\mathrm{TI}$ de Panambizinho, Fogão Ecológico via PNUD e o II Seminário de Saúde Mental Indígena

\subsection{Dos aspectos metodológicos}

Feitas estas considerações históricas, grafamos que elas são indispensáveis para entender de maneira contextualizada a feitura do nosso trabalho de campo e o seu respectivo foco centrado na compreensão de políticas públicas, ausentes ou presentes na $\mathrm{TI}$ de Panambizinho. Passamos, então, aos esclarecimentos quanto aos aspectos principais que nortearam a metodologia empregada, bem como, à tessitura analítica.

Desde 2008, conforme outrora fora mencionado, uma das autoras desenvolve pesquisas e extensões junto à TI Panambizinho. Todas, aliás, tendo como pano de fundo a relação entre indígenas kaiowá e o Estado ${ }^{7}$ sob a perspectiva antropológica que culmina na etnografia (BECKER, MULLER e ALMEIDA, 2012). Aqui cabe destacar que a etnografia resulta da interação do pesquisador com seus interlocutores através da "observação participante", que não se confunde com a realização, por exemplo, de entrevistas. Isto porque, a com-vivência prolongada do antropólogo junto a e na comunidade tende a fazê-lo perceber as nuances que estreitam e/ou distanciam os "ditos e os feitos" de quem lá reside, conforme apontado por Clifford Geertz (1978). Ao mesmo tempo, permite que a comparação sempre norteadora do olhar do antropólogo leve-o a perceber que entre o "nós" e o "eles/outros" há

\footnotetext{
${ }^{7}$ Concebido de maneira plural - União, Estados, Município, organizações não governamentais que atuam com verba de projetos advindos do governo, etc.
}

Espaço Ameríndio, Porto Alegre, v. 7, n. 2, p. 172-204, jul./dez. 2013. 
semelhanças e não necessariamente distanciamentos. Mas mais do que isto, se como bem destaca Geertz (1978, p. 32) "os antropólogos não estudam as aldeias (tribos, cidades, vizinhanças...), eles estudam nas aldeias", torna-se de fundamental importância complementar que estas aldeias podem ser "arquivos/documentos" (BECKER, SOUZA e OLIVEIRA, 2013). Quanto à etnografia a partir de documentos ou em "aldeias arquivos":

\begin{abstract}
A feitura de etnografia é realizada, em regra, nas aldeias (Geertz 1978), porém, estas aldeias podem ser "arquivos" no sentido restrito aos "documentos", e não apenas quando a abordagem antropológica dialoga com a história. Neste sentido, Leite (2002: 35), ao remarcar as particularidades do "fazer antropologia" nos laudos, refere-se ao "passado etnográfico" como o resultado advindo da "memória, do pesquisador com os documentos e com os seus entrevistados". É o que Sérgio Carrara denomina de "aldeias arquivos", face ao fato de sua concretude se reduzir a "um amontoado de papéis, fichas, cópias, anotações e resumos feitos a partir de documentos que, pacientemente ou não, vaise coligindo em bibliotecas ou empoeirados arquivos" (Carrara 1998: 53-54). Aqui, nossas aldeias são os julgamentos judiciais categorizados também como "acórdãos" pelo discurso nativo êmico e se restringem ao Tribunal de Justiça do de Justiça do Mato Grosso do Sul, por certas particularidades desta região brasileira (BECKER, SOUZA e OLIVEIRA, 2013, p. 108, sic).
\end{abstract}

Outro aspecto relevante para adentrarmos no campo de nossos ensaios analíticos é o de delimitarmos qual a definição de política pública utilizada no presente trabalho. Destarte, bebemos na definição de Celina Souza, para quem:

Pode-se, então, resumir política pública como o campo do conhecimento que busca, ao mesmo tempo, "colocar o governo em ação" e/ou analisar essa ação (variável independente) e, quando necessário, propor mudanças no rumo ou curso dessas ações (variável dependente) (SOUZA, 2006, p. 26).

Complementando esta definição, entendemos, outrossim, políticas públicas como "conjunto de políticas intencionais que visam satisfazer às necessidades básicas de uma população" (SOUZA, 2006, apud

Espaço Ameríndio, Porto Alegre, v. 7, n. 2, p. 172-204, jul./dez. 2013. 
JOHNSON, 2011, p. 181). Neste sentido, Johnson (2011) salienta ser necessário para compreensão, considerar os agentes, os setores sociais e as instituições formais para entender o processo da política pública.

Familiarizado o/a leitora/a quanto aos nossos métodos ou "formas de coleta de nossos dados", passemos ao mergulho do que compôs nossas "aldeias".

\subsection{Do Campo e nossos ensaios analíticos}

\subsubsection{Projeto da Carteira Indígena em Panambizinho}

Em outubro de 2010, após algumas reuniões na TI de Panambizinho, congregando a maioria dos (aproximados) trezentos habitantes de diferentes gerações e gêneros, a comunidade participou da proposta do projeto Carteira Indígena.

Grosso modo, essa se refere a "projetos fome zero e desenvolvimento sustentável em comunidades indígenas" capitaneados por quatro instituições ligadas ao governo federal. São elas: Ministério do Meio Ambiente, Ministério do Desenvolvimento Social e Combate à Fome, SESAN - Coordenação Geral de Apoio a Grupos Vulneráveis e SEDR - Departamento de Extrativismo. Para tanto, os interessados em participar devem seguir um itinerário burocrático que envolve a escolha da faixa de verba a qual concorrerá, o preenchimento do formulário do projeto, o envio do projeto que deverá necessariamente estar em nome de uma dada instituição caracterizada enquanto associação e/ou organização não governamental, dentre outros. Eis o nó, a partir do qual as relações interculturais e interétnicas acabam não convergindo para, por exemplo, a autonomia da comunidade concorrente. Sugerimos a reiteração da noção de "tutela" que perpassa esta iniciativa do governo federal face, em especial, ao conceito de etnodesenvolvimento. Vamos com vagar.

Se a noção de etnodesenvolvimento (STAVENHAGEM, 1984, p. 57) congrega, dentre outros aspectos, o pleno domínio das relações com o Estado e agências do governo, a ponto de a sociedade indígena definir 
os nortes dessas relações (algo convergente para a "consulta prévia"), não nos parece que tal sai do plano ideal.

No caso específico do projeto intitulado Projeto plantio de mudas frutíferas do cerrado: o resgate cultural a partir da relação das mulheres mães de Panambizinho e seus filhos, alunos da escola Pa'i ChiquitoChiquito Pedro (Terra Indígena Panambizinho), encaminhado pela TI Panambizinho, tais obstáculos tornaram-se evidentes. Sublinhamos um deles, a nosso ver, principal: a escolha da associação responsável pelo envio do projeto e recebimento/administração de futura verba. No caso em tela, a fim de que esta "autonomia" fosse resguardada, a sugestão dada à época por uma das autoras do presente trabalho aos envolvidos no projeto Carteira Indígena fora de que a associação fosse da comunidade. Neste sentido, a única opção naquele momento era a Associação de Pais e Mestres da Escola Pa'i Chiquito - Chiquito Pedro. Assim fora feito; porém, no ato do envio deparamo-nos com algumas pendências da referida associação quanto à burocracia estatal, tais como a obrigatoriedade de inscrição no Cadastro Nacional de Pessoa Jurídica (CNPJ). Ademais, pendências que demandam para todo e qualquer sujeito (independentemente da etnia) uma proximidade com a linguagem técnica da burocracia e que obstaculizaram a TI Panambizinho.

Sugerimos, então, que no projeto da Carteira Indígena acima citado há a existência de nuanças tutelares na relação com o Estado, à medida que o Programa não procede da precedência de concessão e respeito à autonomia (em meio à burocracia) das comunidades indígenas para a consecução, por exemplo, de verbas por parte deles que os façam gestar as terras já homologadas para além de subsídios como o benefício do programa bolsa família8.

\footnotetext{
${ }^{8}$ O Programa Bolsa Família é um programa de transferência direta de renda que beneficia famílias em situação de pobreza e de extrema pobreza em todo o país. O Bolsa Família integra o Plano Brasil Sem Miséria, que tem como foco de atuação os 16 milhões de brasileiros com renda familiar per capita inferior a $\mathrm{R} \$ 70$ mensais e está baseado na garantia de renda, inclusão produtiva e no acesso aos serviços públicos (BRASIL, 2013). Em Panambizinho, conforme dizeres de uma de suas lideranças, com quem interagimos ao longo destes anos, atualmente a maioria das aproximadas 84 famílias vive de subsídios do governo como a bolsa família, sendo um número significativamente menor daqueles que trabalham com registro em carteira de trabalho ou gozam de benefício de aposentadoria por idade ou por tempo de trabalho.
}

Espaço Ameríndio, Porto Alegre, v. 7, n. 2, p. 172-204, jul./dez. 2013. 


\subsubsection{Projeto do Fogão Ecológico - Programa das Nações Unidas para o Desenvolvimento (PNUD)}

No tocante ao fogão ecológico financiado pelo Programa das Nações Unidas para o Desenvolvimento (PNUD) não foi diferente. Com seu lema "empoderando vidas, fortalecendo nações" (PNUD, 2013), o PNUD cientificou, segundo um de nossos interlocutores, os moradores da TI Panambizinho há meses atrás sobre a implantação dos fogões ecológicos em cada uma das moradas. Com uma estrutura que extrapola o tamanho da maioria das casas das mais de oitenta famílias de Panambizinho, não tardou muito para que um de nossos interlocutores, Reginaldo, fizesse questão de nos (re)contar sobre como se deu a chegada do fogão ecológico. Inicialmente por vídeo produzido com o auxílio da associação de jovens indígenas da Jaguapiru (2013) e depois visualmente mostrando-nos ao menos 5 (cinco) dos instalados em diferentes momentos e famílias. Notamos que, na foto abaixo, a estrutura está vazada - sem paredes - porque segundo os interlocutores, moradores nesta casa que abrigou em seu terreno o fogão ecológico, conforme Figura 2, as paredes começaram a se mexer, inutilizando assim qualquer uso por parte dos indígenas, sobretudo face à presença de crianças.

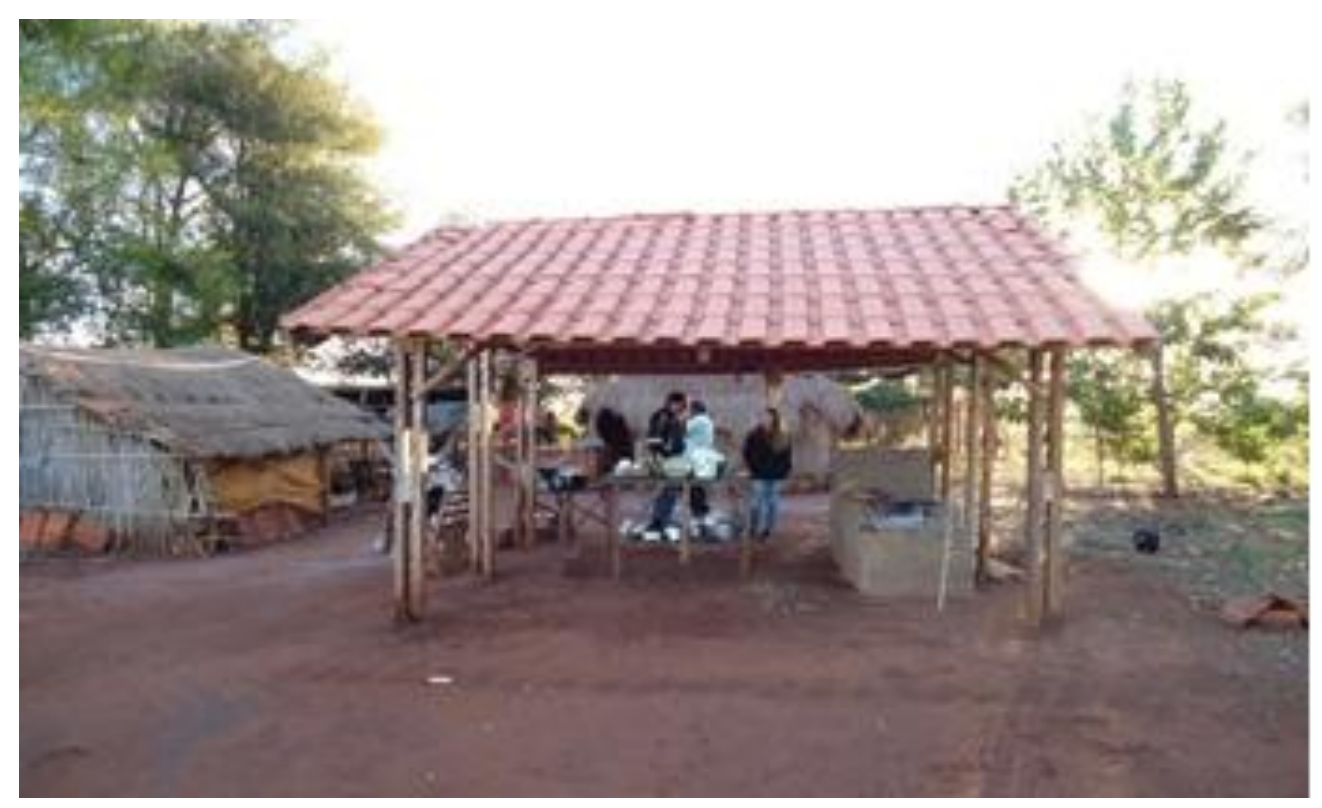

Figura 2. Foto de um dos fogões ecológicos da TI Panambizinho. 
Se não teve uso por parte dos indígenas, o mesmo não se deu com relação às galinhas desta família. O forno transformou-se em suas casas cobertas e eis a ressignificação neste lócus do fogão ecológico, tal como visualizamos na Figura 3.

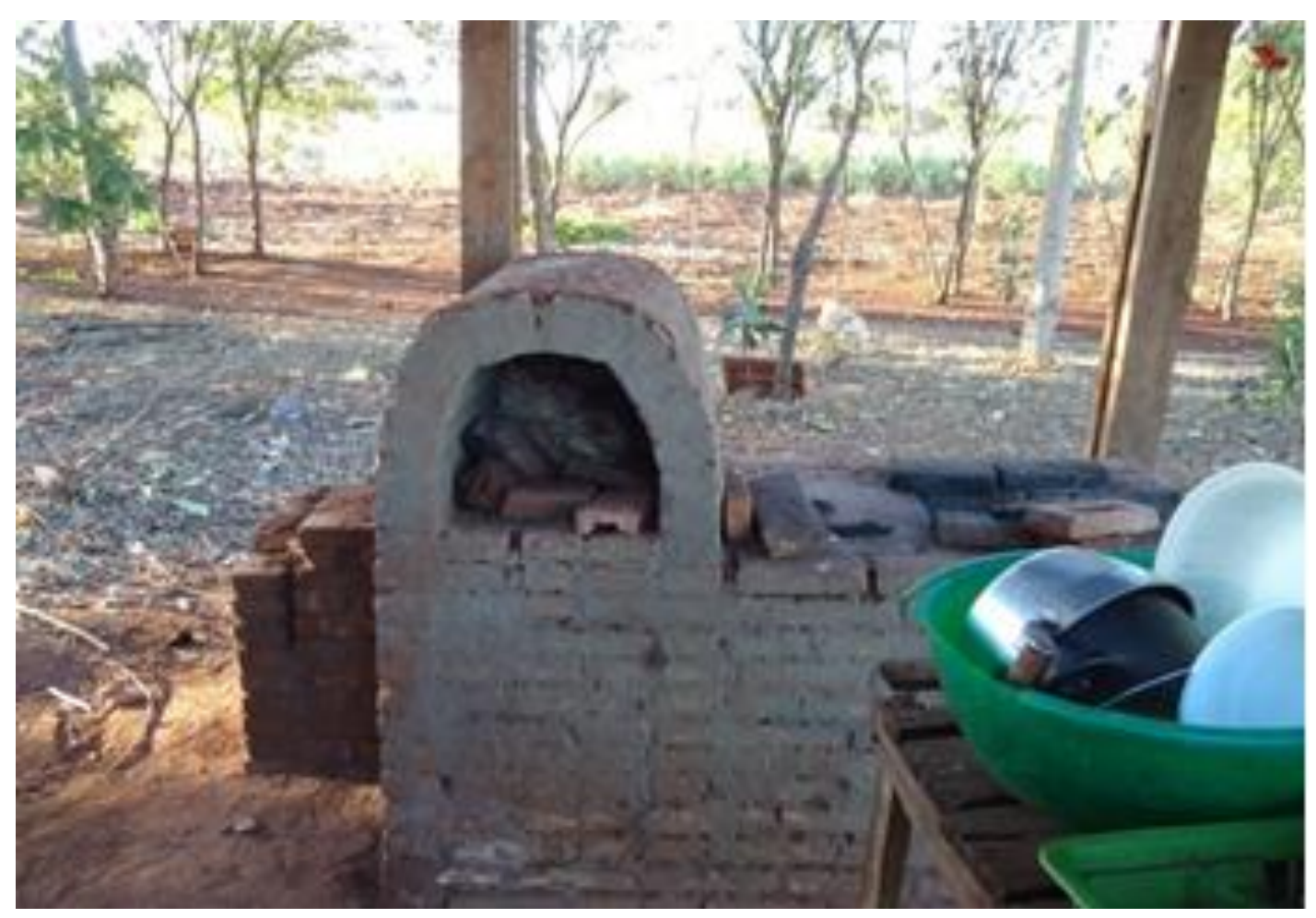

Figura 3. Fogão ecológico e seu uso de abrigo à galinha.

De maneira sintética, salientamos que as inovações e benefícios advindos do fogão ecológico foram a nós frisados por parte dos Kaiowá de Panambizinho como algo que deu certo em solos nordestinos, e nos parece sem que fossem levadas em consideração tanto as diferenças climáticas da região do sul de MS quanto a significação de como o "fogo doméstico" opera as relações entre os Kaiowá.

Talvez não por um acaso, em duas outras casas, para que se usasse o mesmo para cozinhar, a estrutura do fogão foi modificada, também quiçá frente ao motivo de que a mulher idosa kaiowá portava dificuldades de locomoção e, então, de permanecer em pé. Quebrou-se a espécie de bancada e o fogão ecológico ficou na altura adequada. Mas, as adequações estão longe de terminar, segundo as narrativas a nós direcionadas. Em outra, conforme observamos na imagem abaixo, tão logo chegamos a casa fomos recepcionados com a seguinte pergunta:

Espaço Ameríndio, Porto Alegre, v. 7, n. 2, p. 172-204, jul./dez. 2013. 
"onde está a chaminé?". Pois bem, era uma das tardes ainda frias da região e o uso dado pelos moradores foi de se manterem aquecidos com o acender do fogão. Entretanto, dentro desta estrutura não vazada a permanência por muito tempo já trazia aos que lá estavam todos os inconvenientes de inalação da fumaça, haja vista que não havia chaminé, conforme se observa na Figura 4.

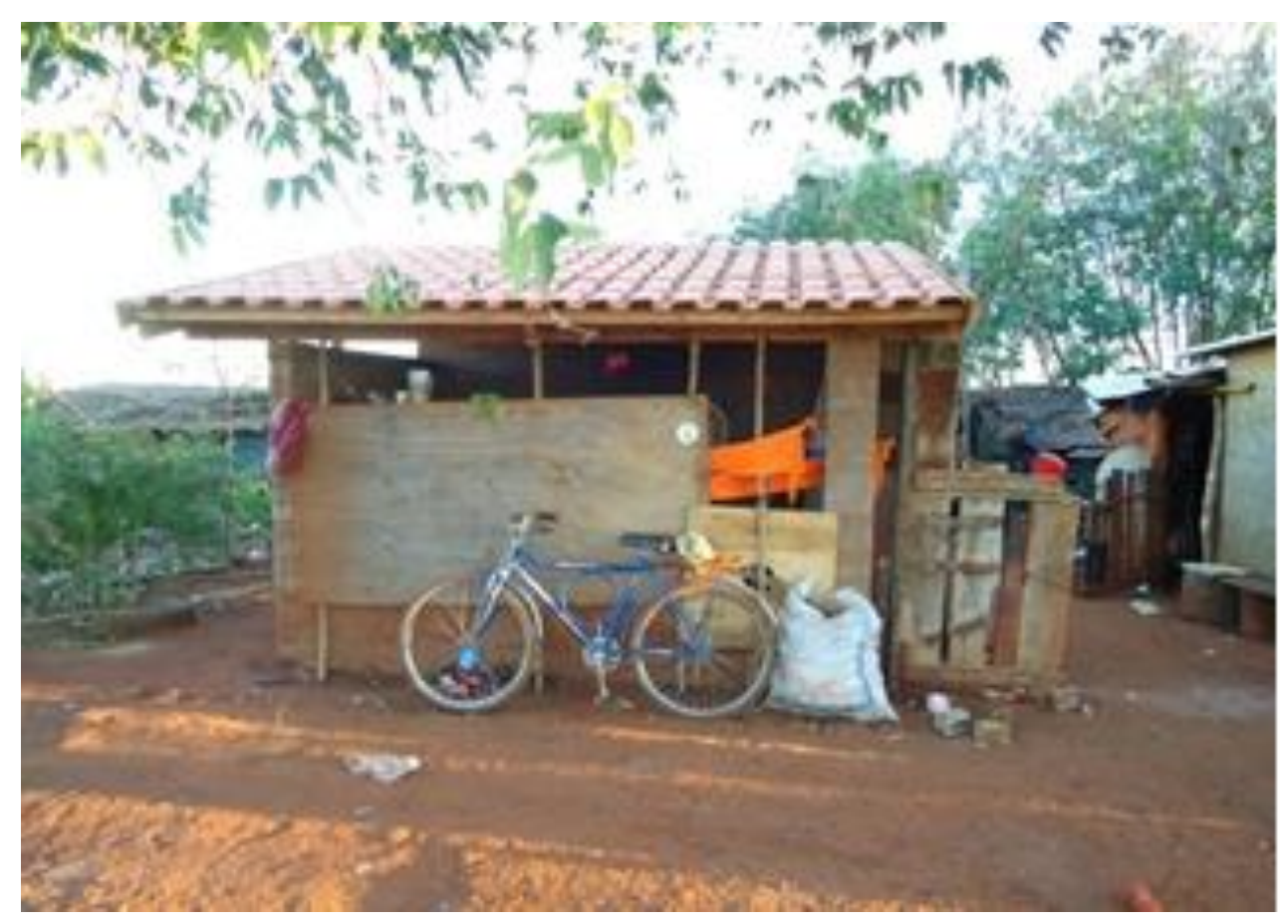

Figura 4. Fogão com estrutura fechada pelos moradores e sem chaminé.

Nota-se que as verbas e a iniciativa do PNUD chegaram à TI Panambizinho; porém, sem que a comunidade tivesse sido consultada quanto à pertinência e ao próprio desejo quanto às instalações do fogão ecológico. Em especial, às indispensáveis adaptações que deveriam anteceder a construção.

\section{A despeito de quaisquer conclusões (...)}

Finalmente, chegamos ao /l Seminário de Saúde Mental Indígena, ocorrido em Dourados/MS entre os dias 07 e 10 de agosto de 2013. Com o visível e presente apoio do Conselho Regional de Psicologia de MS (CRP/MS), o evento voltou-se à interação entre indígenas da Região e 
profissionais de diferentes áreas, indígenas e não indígenas. Mas, mais do que isto, percebemos que o evento privilegiou a construção de um espaço de trocas linguísticas simétricas, ao invés de assimétricas no sentido bourdiano (BOURDIEU, 1998). Sua ousadia residia no trabalho dispendido por docentes, graduados, pós-graduados, pós-graduandos e graduandos ${ }^{9}$, que convergia para a produção de sínteses das falas de cada um dos palestrantes que participaram das mesas redondas matutinas, vespertinas e noturnas. Tais sínteses eram resultado das proposituras que vinham à tona nas articulações dos palestrantes e, depois, culminaram no documento produzido pela equipe antes citada, a fim de subsidiar os debates e deliberações da plenária ocorrida na tarde do dia 09 de agosto de 2013. Essa, por sua vez, seria o documento oficial e fruto das trocas linguísticas capaz de sustentar os debates e as reivindicações a ocorrerem na Conferência Nacional de Saúde (Mental) Indígena.

Assim, das 68 propostas deliberadas no evento douradense, 49 fazem menção explícita à ausência e à presença estatal que caminha na contramão do que se concebe enquanto políticas públicas.

Por conseguinte, estes / Encontro Nacional de Psicologia, Povos Indígenas e Direitos Humanos e II Seminário de Saúde Mental Indígena de Mato Grosso do Sul foram o momento em que as fronteiras mencionadas na primeira parte deste artigo foram "rompidas" e "realçadas" pelos mais de 60 profissionais nas áreas de psicologia, direito, antropologia, lideres indígenas, movimento social indígena e outras representações políticas do Estado brasileiro, que debateram por meio de mesas redondas a temática da saúde mental indígena.

Com um público de mais de mil inscritos, os eventos tiveram um caráter, como já ressaltado, de levantar propostas para a Conferência Nacional de Saúde Mental Indígena. Destarte, as figuras 5 e 6, a seguir, representam uma modesta tabulação destas propostas levantadas e aprovadas neste evento. Se atentando, entretanto, às políticas públicas de alçada governamental, ou relativas a um conjunto de ações do Estado

\footnotetext{
${ }^{9}$ Com a participação dos bolsistas e voluntários do PROGRAMA PROEXT 2013, coordenado por Simone Becker; mestrandos/mestres do PPGAnt e do PPGS, bem como demais acadêmicos da psicologia e graduados em psicologia da especialização junto ao HU/UFGD. Cabe, em especial, remarcar que foi graças à articulação do professor Conrado Neves Sathler (FCH/UFGD), integrante também do PROEXT, que tal trabalho de campo foi possível de ser realizado, e, sobretudo, toda a organização e relação da UFGD com o citado evento.
}

Espaço Ameríndio, Porto Alegre, v. 7, n. 2, p. 172-204, jul./dez. 2013. 
e Sociedade Civil. Para tanto, nos debruçamos sobre as 49 propostas e definimos as instituições/órgãos ou organizações que poderiam executar ou fomentar ações essenciais para a efetivação de saúde mental (SM) indígena.

Como resultado da Figura 5, podemos caracterizar as propostas como complementares e conjuntas para a implantação das referidas políticas públicas. Deste modo, elegemos, adiante, algumas propostas que permitem afirmar a sua transitoriedade entre os órgãos executores ou fomentadores das ações.

Por conseguinte, aa Figura 5 nos traz ações compartilhadas entre as instituições, com uma concentração maior na Secretaria Especial de Saúde Indígena (SESAl), confirmando a tendência temática "saúde mental" explorada pelo evento. Entretanto, há uma transversalidade que atinge outras áreas do saber, permitindo interpretar o esforço do evento em trabalhar "saúde mental" considerando o indivíduo como um todo, ou seja, seus fazeres e suas peculiaridades. Destarte, vemos que as propostas encontram entrada em diversas áreas, como Ministério da Educação e Cultura (MEC), Fundação Nacional do Índio (FUNAI), Ministério do Desenvolvimento Social e Combate a Fome (MDS)/ Centro de Referência Especializado de Assistência Social (CREAS), Conselhos Locais (L) Nacionais (N), entre outros.

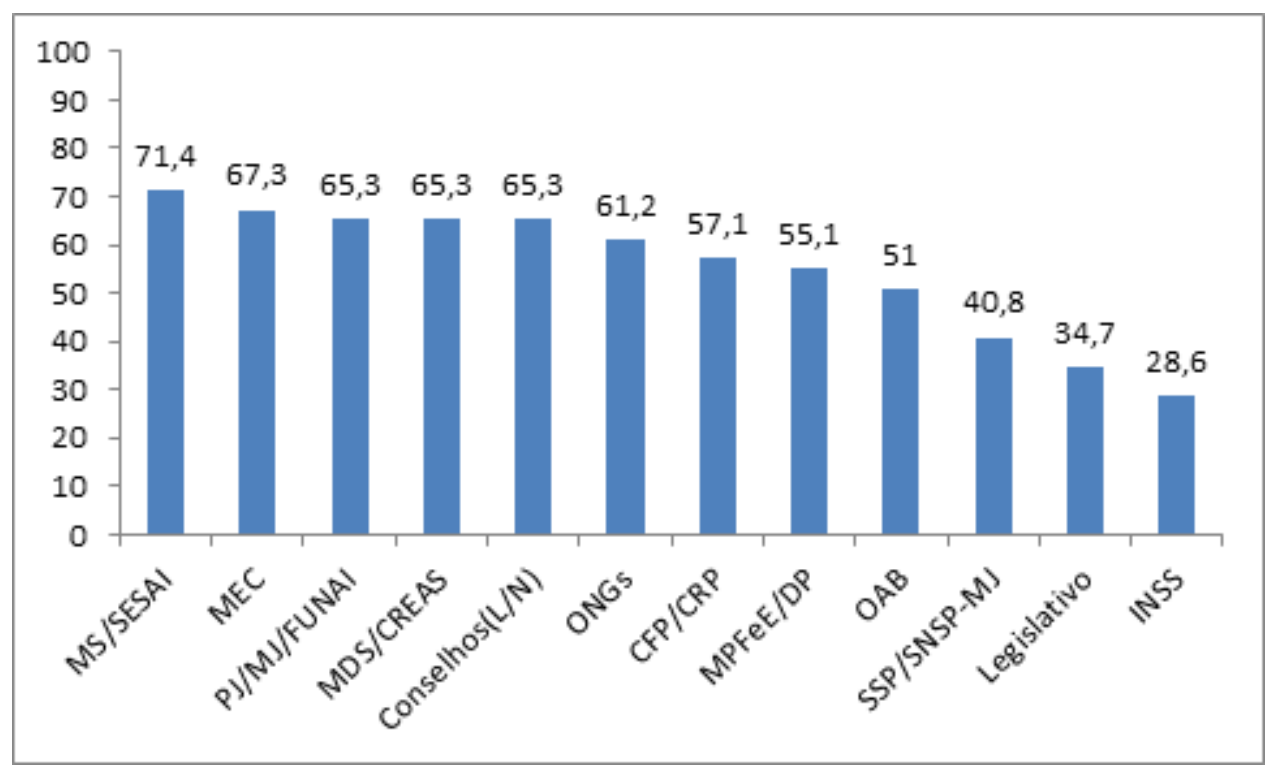

Figura 5. Propostas de Políticas Públicas aprovadas no I Encontro Nacional de Psicologia e instituições/órgãos/organizações executores/fomentadores.

Espaço Ameríndio, Porto Alegre, v. 7, n. 2, p. 172-204, jul./dez. 2013. 
Tania Pacheco (2013), em sua apresentação em uma das mesas do referido evento, destacou pesquisa que culmina no mapa de violência ambiental em "terras brasilis": a maioria (quase) absoluta dos conflitos ambientais se dá por questões agrárias, de norte a sul deste país. Dado corroborado pelo demonstrativo da Figura 6, em que apresenta a necessidade de ações urgentes das Secretarias de Segurança Pública (SSP), em âmbito Estadual, e, Secretaria Nacional de Segurança Pública (SNSP), em âmbito federal, principalmente no tocante à atenção integral da pessoa indígena (proposta 7); entendendo as ações de políticas públicas na área de segurança pública como compromisso e responsabilidade do Estado brasileiro na questão da demarcação de terras indígenas (proposta 29); ou entender como indissociável a demarcação de terra da saúde mental dos povos indígenas (proposta 30).

Outro dado importante, apresentado na Figura 6 como ação urgente, é a ação legislativa no âmbito dos entes federativos, principalmente na aprovação do projeto de Lei que cria o Conselho Nacional de Política Indígena (CNPI) (proposta 19); e a criação "junto às mulheres indígenas de políticas e ferramentas para enfrentar a violência" (proposta 42). Estas propostas trespassam vários órgãos e instituições, como Organizações Não Governamentais (ONGs); SSP; SNSP; Ministério Público Federal e Estadual; Conselho Federal de Psicologia (CFP); CREAS; OAB; poder judiciário, entre outros. Entretanto, no caso legislativo, a proposta, no nosso entender, se torna emergencial, uma vez que a elaboração de projetos de lei permite incluir as especificidades sofridas, por exemplo, pelas mulheres indígenas e suas particularidades de gênero face ao vetor étnico/racial.

Deste modo, entendemos evitáveis os desperdícios de recursos financeiros em relação às políticas públicas, quando o gestor dessas percebe e se atenta para as necessidades do público alvo da política pública, como podemos verificar na proposta 28 aprovada pela assembleia do evento:

Políticas Públicas mais efetivas para os povos indígenas e não iniciativas paliativas; mais oportunidade $e$ representatividade indígena nos órgãos gestores. 
Garantir o direito do indígena de falar sua língua e existir enquanto cultura.

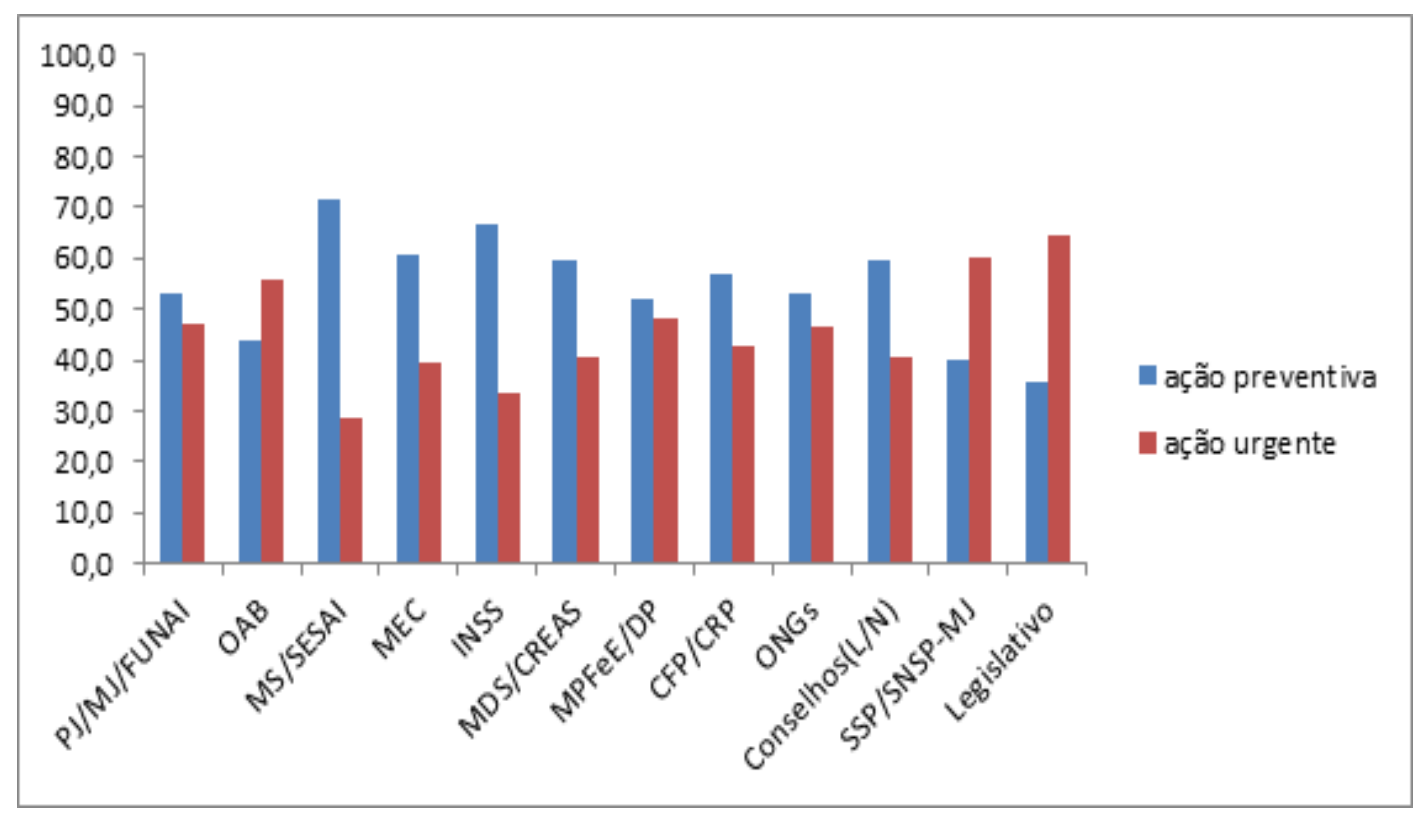

Figura 6. Políticas públicas de ação preventiva/urgente e instituições/órgãos executores ou fomentadores

Logo, as políticas públicas devem atender a legitimidade qualificada pelas representações indígenas, algo intrínseco à categoria êmica "consulta prévia" - da Convenção 169 da OIT. Outro ponto em destaque, objeto que tratamos neste artigo, se refere à carteira indígena e aos processos ou itinerários burocráticos impeditivos de sua implantação. A grande assembleia presente ao evento atentou para a desburocratização e à acessibilidade para a solicitação de execução de políticas públicas. Na proposta 34 como podemos analisar a seguir, os participantes deliberaram pela: "Promoção de formas de acesso à documentação básica (civil) dos indígenas, para que haja menor burocratização junto aos benefícios do Instituto Nacional de Seguridade Social (INSS)". Essa sinaliza para a necessidade dos povos indígenas serem (efetivamente) escutados e atendidos pelo poder público, que criaria instrumentos céleres para a aquisição de seus direitos materiais e imateriais.

Por conseguinte, ao analisar as propostas levantadas pelas lideranças indígenas e demais representações no seminário, e traçando 
relações com o que ocorreu na TI Panambizinho nos processos do Projeto da Carteira Indígena e implantação do Fogão Ecológico, elas nos possibilitam entender a teoria de Souza (2006), em que política pública é um campo do conhecimento que busca "colocar o governo em ação". Portanto, analisando as ações governamentais e apontando seus equívocos e acertos, poderemos quiçá colaborar para com os gestores públicos, lideranças e movimento indígena na efetivação e resultados pretendidos pela política pública e comunidade.

No que se refere à Universidade e à academia, como representação atuante no seminário de saúde mental e presente, também, em campo na pesquisa, ensino e extensão, destacamos a contribuição da sociologia que neste caso se amplia, uma vez que não se prende na "pseudoneutralidade científica", como podemos verificar nas ponderações de Burawoy:

Nós podemos distinguir diferentes tipos de sociologia pública e falar de diferentes públicos. Entretanto, como esses dois lados - o acadêmico e o extra-acadêmico são trazidos para um diálogo? Por que alguém deveria nos escutar mais do que a outras mensagens alardeadas pela mídia? Alan Wolfe (1989), Robert Putnam (2001) e Theda Skocpol (2003) foram além e advertiram que os públicos estão desaparecendo destruídos pelo mercado, colonizados pela mídia ou bloqueados pela burocracia. A própria existência de uma extensa faixa de sociologia pública, porém, sugere que não existe tal escassez de públicos, quando nos preocupamos em procura-los. Mas nós temos muito a aprender sobre como engajá-los (BURAWOY, 2009, p. $26, s i c)$.

Neste trabalho buscamos o público indígena; entretanto, encontramos nossa desumanidade histórica. Portanto, fica a pergunta persistente: Como voltar a respirar depois de séculos de desumanidade?

\section{Referências bibliográficas}

BECKER, Simone; MULLER, C. B.; ALMEIDA, Ellen Cristina de. Diálogos entre antropologia, direito e políticas públicas: o caso dos indígenas no sul de Mato Grosso do Sul. Dourados: UFGD, 2012. v. 1. 
BECKER, Simone; SOUZA, Olivia Carla; OLIVEIRA, Jorge Eremites de. A prevalência da lógica integracionista: negações à perícia antropológica em processos criminais do Tribunal de Justiça do Mato Grosso do Sul. Etnográfica, Lisboa, n. 17. v. 1, p. 97-120, 2013.

BOURDIEU, Pierre. O que falar quer dizer: economia das trocas linguísticas. São Paulo: Edusp, 1998.

BRAND, Antonio Jacob. O impacto e a perda da terra sobre a tradição Kaiowá/Guarani: os difíceis caminhos da palavra. 1997. 382 f. Tese (Doutorado em História), Pontifícia Universidade Católica de Porto Alegre, Rio Grande do Sul, 1997.

BRASIL. Estatuto do Índio, Lei n. 6.001 de 19 de dezembro de 1973. 1973. Disponível em: http://www.funai.gov.br/quem/legislacao/estatuto_indio.html . Acesso em: 15 set. 2013.

BRASIL. Ministério do Desenvolvimento Social e Combate a Fome (MDS). 2013. Disponível em: http://www.mds.gov.br/bolsafamilia. Acesso em: 22 nov. 2013.

BRITO, Antonio José Guimarães. Direito e Barbárie no (i)mundo moderno: a questão do Outro na civilização. Dourados: UFGD, 2012.

BURAWOY, Michael. Por uma sociologia pública. In: BRAGA, Ruy (Org.). Por uma sociologia pública. São Paulo: Alameda, 2009. p. 15-66.

BUTLER, Judith. O limbo de Guantánamo. Novos Estudos CEBRAP, São Paulo, v. 1, n. 77, p. 223-231, 2007.

CORREIA, Diogo Cristófari. Os protagonistas nos processos de confinamento de indígenas sul mato-grossenses. In: MÜLLER, Cíntia Beatriz; ALMEIDA, Ellen Cristina de; BECKER, Simone (Org.). Diálogos entre antropologia, direito e políticas públicas: o caso dos indígenas no sul de Mato Grosso do Sul: Dourados: UFGD, 2012. p. 115-134.

GEERTZ, Clifford. A Interpretação das Culturas. Rio de Janeiro: Zahar Editores, 1978.

JOHNSON, Alfredo Guillermo. Os alicerces das políticas públicas: adversidades da universalização. In: FAISTING, André Luiz; FARIAS, Marisa de Fátima Lomba de (Org.). Direitos Humanos, Diversidade e Movimentos Sociais: um diálogo necessário. Dourados: UFGD, 2011. p. 179-204.

LENHARO, Alcir. Colonização e trabalho no Brasil: Amazônia, Nordeste e CentroOeste. Campinas: Unicamp, 1986.

MACIEL, Nely Aparecida. História da Comunidade Kaiowá da Terra Indígena Panambizinho (1920-2005). Dourados: UFGD, 2012. 
MARTINS, José de Souza. Fronteira: a degradação do outro nos confins do humano. São Paulo: Contexto, 2009.

OLIVEIRA, Ariovaldo Umbelino de; FARIA, Camila Salles de. O processo de constituição da propriedade privada da terra no Brasil. Encontro de Geografia da América Latina, EGAL. 2009. Disponível em: http://www.gesp.fflch.usp.br/es/node/112 . Acesso em: 09 jul. 2013.

PACHECO, Tania. Conflito ambiental. Disponível em: http://www.conflitoambiental.icict.fiocruz.br/index.php?pag=equipe. Acesso em: 15 set. 2013.

PEREIRA, Levi Marques. Parentesco e organização social Kaiowá. 1999. 414 f. Dissertação (Mestrado em Antropologia Social) - Instituto de Filosofia e Ciências Humanas, Universidade Estadual de Campinas, 1999.

PEREIRA, Levi Marques. Imbricação entre violência nas atuais reservas e a impossibilidade dos Kaiowá e Guarani seguirem praticando seu modelo de organização social. In: CIMI - Conselho Indigenista Missionário. As violências contra os povos indígenas em mato grosso do sul e do Bem Viver por uma Terra Sem Males Dados: 2003-2010. Cidade: CIMI - Regional Mato Grosso do Sul, 2011. p. 44-47.

PNUD. Programa das Nações Unidas para o Desenvolvimento. 2013. Disponível em: http://www.pnud.org.br . Acesso em: 10 ago. 2013.

SOUZA, Celina. Políticas Públicas: uma revisão da literatura. Sociologias, Porto Alegre, v. 8, n. 16, p. 20-45, jul./dez. 2006.

SILVEIRA, Nádia Heusi. Imagens de abundância e escassez: comida guarani e transformações na contemporaneidade. 2011. 266 f. Tese (Doutorado em Antrolopologia Social) - Centro de Filosofia e Ciências Humanas, Universidade Federal de Santa Catarina, Florianópolis, 2011.

STAVENHAGEN, Rodolfo. Etnodesenvolvimento: uma dimensão ignorada no pensamento desenvolvimentista. Anuário Antropológico, São Paulo, n. 84, p. 11-44, 1985.

TELLES, Edward. Racismo a Brasileira: uma nova perspectiva sociológica. Rio de Janeiro: Relume Dumará, 2003.

VIETTA, Katya. Histórias sobre terras e xamãs kaiowá: territorialidade e organização social na perspectiva dos Kaiowá de Panambizinho (Dourados, MS) após 170 anos de exploração e povoamento não indígena da faixa de fronteira entre o Brasil e o Paraguai. 2007. 512 f. Tese (Doutorado em Antropologia Social) - Faculdade de Filosofia, Letras e Ciências Humanas, Universidade de São Paulo, 2007.

Espaço Ameríndio, Porto Alegre, v. 7, n. 2, p. 172-204, jul./dez. 2013. 


\section{ANEXO}

I Encontro Nacional Psicologia,

\section{Propostas finais Aprovadas em Plenário}

\section{CFP (Conselho Federal de Psicologia):}

1. Promover um encontro interdisciplinar com profissionais que atuam na psicologia cultural, agenciando intercâmbio/diálogo com as áreas da antropologia, etnologia, história e geografia. Além disso, disponibilizar referencial bibliográfico dessas áreas em uma página específica no portal do CFP.

2. Promover registros e criar meios de divulgação das experiências dos psicólogos na saúde indígena, avaliados também pela comunidade.

3. Promover debates, dentro do Sistema Conselhos, acerca dos critérios de inserção dos profissionais valorizando a identificação do profissional com a organização social, crenças e culturas dos povos indígenas e encaminhando aos órgãos competentes os resultados desses debates.

4. Promover a discussão sobre a construção das políticas públicas indígenas e a inserção dos psicólogos nas mesmas, sobretudo no campo da atenção psicossocial considerando a perspectiva dos povos indígenas sobre suas necessidades e contextos específicos.

5. Trabalhar juntamente com a comunidade indígena acerca do entendimento da proposta de trabalho da Psicologia no contexto da saúde indígena. 
6. Promover o debate entre Psicologia e Saúde Indígena que leve em consideração o direito à alteridade e de maneira intercultural.

7. Criar fóruns de debate para atuação profissional que possibilite uma aproximação dos psicólogos com os povos indígenas assegurando um diálogo intercultural acerca da prática profissional dos psicólogos junto a essas comunidades.

8. Oportunizar a continuidade do encontro nacional de psicologia, povos indígenas e direitos humanos, bem como seminários estaduais e municipais.

9. Aproximar o Sistema Conselhos e as instituições formadoras para a ampliação do diálogo sobre as questões etnoculturais.

10. Regionalizar através do Sistema Conselhos as discussões referentes à atuação do psicólogo nas políticas públicas indígenas, valorizando as experiências destes profissionais nos diferentes locais ou contextos em que estão inseridos.

11. Criar ações de valorização do plurinacionalismo e da sociedade pluriétnica brasileira.

12. Apoiar o processo de auto-organização do campo profissional de psicologia e povos indígenas e a realização de um encontro nacional que envolva os trabalhadores das políticas públicas e os povos indígenas.

\section{Universidades:}

1- Capacitar profissionais de saúde indígena quanto à saúde mental, à cultura e valores indígenas. 
2- Estimular o diálogo entre instituições de ensino e as comunidades indígenas para o ensino, a pesquisa, estágios, a extensão em programas voltados à Interculturalidade, incluindo a inserção de tais discussões nas "grades curriculares" das graduações, pós-graduações e residências tais como, direito, psicologia, medicina, etc, respeitando as decisões da comunidade.

3- $\quad$ Aumento do número de vagas e investimento em programas de Residência Multiprofissional em Saúde coletiva que contemplem os contextos da saúde indígena, com a oferta de campos/cenários de práticas e teorias.

4- $\quad$ Aproximar o conceito de saúde e doença sob a perspectiva das equipes multidisciplinares e das populações indígenas.

5- Aproximar a universidade dos povos indígenas e promover ações de valorização de sua cultura contribuindo efetivamente para política de permanência do estudante indígena e incentivo a professores e pesquisadores indígenas.

6- Investir na ampliação do programa PET em Saúde Indígena.

7- Desenvolvimento de estudo de práticas comunitárias, de cuidado, de resistência, de resiliência e resolutividade, valorizando as capacidades dos povos indígenas, deslocando o foco do discurso da vulnerabilidade e do sofrimento.

\section{3 - Governo e V Conferência Nacional de Saúde Indígena:}

1. Oportunizar cuidados de saúde mental a todos os trabalhadores de saúde indígena.

2. Ampliar a discussão e entendimento da sociedade civil, poder público e terceiro setor acerca do significado da terra para os povos indígenas. 
3. Focar o trabalho de saúde mental nas gerações mais jovens, que estão mais vulneráveis, em relação da inconsistência entre o conhecimento tradicional e as possiblidades materiais disponíveis.

4. Aumentar número de profissionais efetivos da área da psicologia, educação e assistência social nas aldeias, a fim de evitar rotatividade nas funções e descontinuidade de serviços.

5. Capacitar profissionais de diferentes áreas que trabalham com a saúde indígena.

6. Potencializar a política de segurança alimentar, incrementando a qualidade, como estratégia para a saúde indígena.

7. Aumentar com urgência, a partir de critérios técnicos, o número de psicólogos e demais profissionais pertinentes a uma atenção integral à pessoa indígena.

8. Fortalecer política de inserção do psicólogo nas escolas das aldeias indígenas.

9. Repensar as possibilidades de inserção do psicólogo em várias áreas que trabalham com saúde indígena (educação, saúde, assistência social).

10. Elaborar e reforçar estratégias de promoção e prevenção da Saúde Indígena.

11. Fortalecer a efetividade da rede de proteção (fóruns, Creas, etc) ao sujeito indígena.

12. Promover ações para discutir possibilidades de geração de renda para a população indígena, vinculadas aos seus contextos de tensões macrossociais. 
13. Reestruturação da rede de atenção psicossocial (RAPS) às populações indígenas.

14. Efetivação da autonomia dos distritos sanitários indígenas.

15. Promover, no nível da SESAI, encontros regulares de profissionais para a discussão, problematização e busca de novas práticas em saúde mental indígena.

16. Construção de uma saúde indígena com atenção diferenciada.

17. Reavaliação do número de Distritos Sanitários Indígenas em razão da dimensão de seus territórios e do número de etnias neles contidos.

18. Reavaliação do número de profissionais em saúde mental nos DSEls (Distrito Sanitário Especial Indígena). Aumento da cobertura dos Programas de Saúde Mental nos e dos territórios indígenas. Fortalecimento e apoio às equipes multidisciplinares.

19. Produção de estratégias politicas para a aprovação do Projeto de Lei que cria o Conselho Nacional de Politica Indígena (CNPI).

20. Que os distritos sanitários tenham autonomia na aplicação dos recursos para trabalho e geração de renda, esporte, cultura, lazer, educação permanente, aquisição de materiais de consumo e materiais didáticos na língua originária, incluindo material para o trabalho lúdico, bem como recursos para a produção de material, diárias e o deslocamento dos profissionais e manutenção de veículos.

21. Incluir na equipe multiprofissional profissionais de atenção da saúde indígena, de humanidades e de ciências agrárias. 
22. Fortalecimento e capacitação de órgãos de controle social para a saúde nas comunidades indígenas (fóruns comunitários, conferências, conselhos).

23. Cobrar o compromisso do poder municipal na saúde indígena, reafirmando o funcionamento da rede de Saúde como responsabilidade compartilhada pelas três esferas de governo.

24. Desenvolver ações de vigilância em saúde: epidemiologia, capacitação para os profissionais que trabalhem com promoção e prevenção ao suicídio e construção de Saúde Mental.

25. Melhorar o transporte e locomoção tanto dos profissionais como dos pacientes, facilitando o acesso aos serviços da rede de saúde.

26. Desenvolver estratégias que garantam um atendimento diferenciado, nas quais os profissionais se identifiquem com as causas indígenas e tenham reconhecimento do espaço que precisa ser respeitado.

27. Integralidade entre Equipe Multidisciplinar de Saúde Indígena (EMSI) e saúde mental - se integrar com os demais profissionais para que possa ser atendido em todos os setores e tentar suprir as necessidades que são apresentadas em cada comunidade.

28. Políticas Públicas mais efetivas para os povos indígenas e não iniciativas paliativas; mais oportunidade e representatividade indígena nos órgãos gestores. Garantir o direito do indígena de falar sua língua e existir enquanto cultura.

29. Tornar pública a questão da demarcação de terra como responsabilidade do "Estado Brasileiro", deslocando o entendimento de que seja esse o motivo de desavença entre os povos indígenas e não indígenas. 
30. Tornar pública a noção de que a Demarcação de terra e a Saúde Mental devem ser entendidas como conceitos indissociáveis, em se tratando de povos indígenas.

31. Organização da rede nos atendimentos da atenção básica, de média e alta complexidade em saúde mental.

32. Fomentar, junto ao MEC e a $\mathrm{OAB}$, a inserção da disciplina de direitos indígenas, ministrada por professores indígenas locais, enquanto uma disciplina, no currículo, em especial naqueles do curso de Direito.

33. Fomentar a implementação da lei $11.645 / 08$, junto ao MEC, a inserção da disciplina história e cultura indígena, enquanto uma disciplina do currículo.

34. Que o governo de MS e a secretaria de direitos humanos, via OAB e Defensoria Pública, promovam formas de acesso a documentação básica (civil) dos indígenas, para que haja menor burocratização junto aos benefícios do INSS.

35. Que o Governo Federal via INSS compreenda as particularidades dos indígenas quanto à solicitação de benefícios, sem determinados documentos.

36. Que o Judiciário (operadores do direito) se atente às inadequações da aplicação do Estatuto do Índio de maneira indiscriminada e contrária à Constituição Federal de 1988 e à Convenção 169 da OIT. Aspecto importante, esquecido ou não conhecido, como por exemplo, nas aplicações de artigos e conteúdos voltados à área criminal.

37. Usar a linguagem dos Direitos humanos como forma de reconhecimento e visibilidade dos povos indígenas. 
38. Garantir um intérprete nas delegacias e sistemas judiciais para homens e mulheres indígenas, pois em situações de vulnerabilidade a língua materna se faz mais evidente.

39. Realizar um trabalho de capacitação/treinamento dentro das delegacias no sentido do indígena poder ser ouvido falando sua língua materna.

40. Informar jovens indígenas, mulheres indígenas, colocando pra elas os seus direitos.

41. Dobrar a segurança e privacidade no atendimento as mulheres vítimas de violência.

42. Criar junto as mulheres indígenas políticas, instrumentos e ferramentas para enfrentar a violência. Essa situação que acontece hoje sobre violência, mulher indígena, juventude, não é de nenhuma cultura indígena, o machismo existe em qualquer cultura, é uma ideologia que devemos desconstruir todos os dias.

43. Promover ações de conscientização, capacitação, e propostas que possam concretizar políticas públicas para que as mulheres indígenas reestabeleçam sua dignidade e respeito que merecem, incluindo os homens nesta discussão. Fortalecendo a aliança entre as mulheres indígenas, de confiança e de respeito nas relações de gênero, para enfrentar todas as situações de violência.

44. Debater acerca do termo "saúde mental" na busca de um novo termo.

45. Que o plano distrital de saúde indígena seja conhecido e efetivado pelas três esferas do governo (federal, estadual e municipal).

46. Que as decisões dos conselhos distritais de saúde indígena sejam respeitadas pelas diferentes esferas de governo. 
47. Fomentar a implementação completa da política nacional de gestão territorial e ambiental de terras indígenas, com a criação dos respectivos conselhos regionais, estaduais e municipais.

48. Discutir com a comissão nacional de residências multiprofissionais em saúde a criação de cotas para indígenas nos programas de residência.

49. Criação da delegacia especial para atendimento da mulher indígena em situação de violência. 